\title{
Pemanfaatan Lahan Pekarangan Rumah dengan Menanam Sayur Mayur untuk Meningkatkan Ekonomi Masyarakat Desa Kelenna Bontongape Kecamatan Galesong Kabupaten Takalar
}

\author{
Herman Sjaruddin', Muh Subar², Istiqfar Aiman ${ }^{3}$, Aswar $^{4}$ \\ ${ }^{1,2,3}$ Sekolah Tinggi Ekonomi Makassar Bongaya \\ ${ }^{4}$ Universitas IndonesiaTimur \\ email : Herman.sjahruddin@gmail.com ${ }^{1}$, istiqfaraiman@gmail.com², muhsubar@gmail.com³ \\ aswar.phobia@gmail.com ${ }^{4}$
}

\begin{abstract}
The issue of land use is the main problem of the people of Kalenna Bontomangape Village, the area of agricultural land is inversely proportional to the productivity of residents in terms of land use, this is due to a lack of knowledge and information on how to manage and utilize unused land (house yards), where land in the yard can be used for planting vegetables, such as radishes, and other types of plants. This activity is a source of meeting household needs as well as a side income for the community. In the process, we use four methods in carrying out activities for home yard land use, namely, education, training, management, and mentoring, which takes 60 days of this activity. Starting with providing the community with knowledge about the importance of managing and utilizing their home yards for growing vegetables through a socialization process that involves the community. Then the community is taught how to cultivate the land so that it can be used to grow vegetables and introduce types of vegetables that are easy to grow and have economic value, and have a relatively short harvest period. Supporting the community in terms of managing and caring for the grown vegetables in the home garden, as well as assistance in managing the harvest up to the stage of marketing the products from the radish.
\end{abstract}

Keywords: land use, vegetables, economic value.

\begin{abstract}
Abstrak
Persoalan pemanfaatan lahan menjadi problem utama masyarakat desa Kalenna Bontomangape. Luas lahan pertanian berbanding terbalik dengan produktivitas warga dalam hal permanfaatan lahan, hal ini diakibatkan kurangnya pengetahuan dan informasi terhadap cara mengelola dan memanfaatkan lahan tak terpakai, yaitu lahan pekarangan rumah dapat dijadikan sebagai tempat dalam menanam sayuran seperti lobak dan tanaman lainnya. Kegiatan ini menjadi sumber pemenuhan kebutuhan rumah tangga serta sebagai pendapatan sampingan masyarakat. Dalam pelaksanaan menggunakan empat metode yaitu edukasi, pelatihan, pengelolaan, dan pendampingan. Kegiatan ini selama 60 hari. Dimulai dengan memberikan pengetahuan kepada masyarakat tentang pentingnya mengelola dan memanfaatkan lahan pekarangan rumah untuk ditanami sayuran melalui proses sosialisasi yang melibatkan masyarakat. Kemudian masyarakat diajarkan cara pengolahan lahan agar dapat digunakan untuk menanam sayuran serta memperkenalkan jenis-jenis sayuran yang mudah ditanam dan memiliki nilai ekonomis, serta memiliki jangka waktu panen yang relatif singkat. Mendampingi masyarakat dalam hal pengelolaan dan perawatan sayuran yang ditanam di pekarangan rumah, serta pendampingan dalam mengelola hasil panen hingga pada tahap memasarkan produk hasil panen lobak.
\end{abstract}

Kata Kunci: pemanfaatan lahan, sayur mayur, nilai ekonomi.

Artikel diterima : 21 Oktober 2020 direvisi :24November 2020 disetujui : 1 Desember 2020 


\section{Pendahuluan}

Bontongape (yang dalam bahasa Makassar artinya daratan), merupakan salah satu desa yang terletak di kecamatan Galesong, kabupaten Takalar, Sulawesi Selatan. Berdasarkan letak geografis desa Bontongape memiliki batas-batas: sebelah utara berbatasan desa Parangbambe, sebelah selatan berbatasan desa Campagaya, sebelah barat berbatasan desa Bontomangape, sebelah timur berbatasan desa Bontoloe.

Desa Bontongape terbagi dalam 5 (lima) dusun yaitu: dusun Bontongape, dusun Romang Sapiria, dusun Ma'minasa, dusun Kampong Parang dan dusun Pa'jangengang. Secara umum keadaan topografi desa Bontongape adalah daerah dataran rendah. Iklim desa Bontongape sebagaimana desa-desa lain di wilayah Indonesia beriklim tropis dengan dua musim, yakni musim kemarau dan musim penghujan.

Dengan letak geografis yang sepenuhnya adalah daratan dan memiliki luas lahan pertanian yang cukup. Perubahan iklim mempengaruhi sektor pertanian baik secara langsung maupun tidak langsung diantaranya melalui efeknya terhadap suhu dan perubahan curah hujan dalam biologi dan fisik lingkungan. (Brown dan Rosenberg 1997 dalam Mestre-Sanchís dan Feijóo-Bello 2009). Perubahan pola curah hujan dapat menyebabkan fluktuasi ketersediaan air, yang dapat berpengaruh terhadap produksi tanaman, selain juga terhadap peluang peningkatan hama dan penyakit. Ketersediaan air merupakan salah satu konsekuensi paling dramatis perubahan iklim untuk sektor pertanian (MestreSanchís, Feijóo-Bello 2009).

Desa Kalenna Bontomangpe yang memiliki iklim curah hujan yang cukup menjadikan salah satu desa yang strategis dalam menggarap lahan pertanian, yang mana dapat menjadikan desa Kalenna Bontongape sebagai salah satu desa penyuplai pangan di Kabupaten Takalar, dalam hal ini adalah beras, sayuran dan buah-buahan, sehingga sebagian besar masyarakat memanfaatkan lahan pertanian sebagai mata pencaharian, namun potensi lahan pekarangan rumah luput dari perhatian masyarakat. Lahan pekarangan rumah dapat memberikan manfaat dalam menunjang kebutuhan gizi keluarga sekaligus untuk keindahan (estetika) (Rauf, Rahmawaty, \& Budiati, 2013).

Namun pada kenyataannya akibat kurangnya informasi dan pengetahuan tentang cara mengoptimalkan lahan pekarangan rumah, banyak lahan yang terbengkalai dan hanya ditumbuhi rumput liar, yang mengakibatkan kurangnya produktivitas lahan. Jika masyarakat dapat memanfaatkan lahan pekarangan rumah dengan optimal, maka hasil yang akan didapatkan yaitu terpenuhinya kebutuhan pangan rumah tangga dan sebagai pendapatan sampingan masyarakat.

Untuk menyelesaikan persoalan yang terjadi, maka masyarakat desa Bontomangape diberikan informasi dalam penge-lolaan lahan dan penanaman sayur lobak. Tanaman lobak adalah tanaman semusim, tingginya dapat mencapai lebih dari $1 \mathrm{~m}$, berakar tunggang dan berwarna putih. Batangnya tegak, lunak dan berwarna putih pucat. Berbunga majemuk dalam bentuk tandan yang terletak di ujung batang. Umbi lobak berwarna putih, berdiameter 2 sampai 4 inci dan panjang 6 sampai 20 inci (Supriati dkk., 2008).

Kegiatan pemanfaatan lahan pekarangan rumah dilakukan dengan cara sosialisasi pada masyarakat dan dilanjutkan dengan praktek pengolahan dan pemanfaatan lahan pada tempat yang telah disediakan. Kegiatan diikuti oleh beberapa warga desa, yang secara langsung diberikan pelatihan cara mengelola lahan dan penggunaan bibit lobak, kemudian diajarkan pula cara mengelola dan merawat lahan pertanian agar masyarakat dapat menjalankan kegiatan ini untuk menunjang ketersediaan pangan keluarga serta menjadi sumber penghasilan tambahan. 
Dalam kegiatan ini masyarakat dapat menghasilkan produk olahan rumah tangga berupa sayur mayur yang mereka tanam pada lahan pekarangan rumah. Jenis tanaman yang dapat ditanam di lahan peka-rangan diantaranya adalah tanaman sayur-sayuran, buah-buahan, obat-obatan, tana-man hias dan sebagainya. Selain dapat di-gunakan untuk konsumsi seharihari, hasil panen dari lahan pekarangan juga dapat dijual untuk sebagai usaha sampingan anggota keluarga (Dwiratna, et al, 2016).

Adapun produk yang dihasilkan yaitu sayuran seperti lobak,sawi,kangkung, dan jenis tanaman lainnya. Kegiatan dengan menanam berbagai jenis tanaman sayur akan menjamin ketersediaan bahan pangan yang beraneka ragam secara terusmenerus, guna pemenuhan gizi keluarga (Riah, 2005). Selain manfaat yang melimpah seperti pemenuhan gizi, Sayuran seperti lobak dalam proses penanaman, perawa-tan, hingga penjualan tergolong mudah, karena lobak adalah salah satu makanan yang digemari oleh masyarakat, dan menjadi salah satu sayuran yang paling laris di pasar tradisional desa Bontongape.

Kegiatan pemanfaatan lahan pekarangan rumah menjadi solusi atas ketersediaan pangan, dimana sebelumnya masyarakat untuk pemenuhan kebutuhan sehari-hari harus membeli produk olahan dapur dengan membeli langsung ke pasar, dengan rata-rata pengeluaran untuk satu keluarga Rp.84.000/minggu, dengan adanya kegiatan pemanfaatan lahan pekarangan rumah, masyarakat dapat melakukan penghematan dalam hal biaya belanja kebutuhan pangan rumah tangga berupa sayur mayur, sehingga masyarakat dapat mengalihkan pengeluaran untuk kebutuhan lainnya.

\section{Pelaksanaan Dan Metode}

Dalam pelaksanaan pengabdian masyarakat yang dilakukan di desa Kalennna Bontongape, kecamatan Gale- song, kabupaten Takalar, dilaksanakan dalam rentang waktu 60 hari pelaksanaan.

Melalui beberapa tahap yaitu : (1) Tahap memberikan edukasi dengan cara sosialisasi kepada masyarakat mengenai cara memanfaatkan lahan pekarangan rumah, kegiatan ini diikuti oleh 10 (sepuluh) warga desa yang dilakukan di salah satu rumah warga, waktu pelaksanaan selama dua hari, serta diperkenalkan tanaman sayur yang memiliki nilai ekonomis tinggi kepada masyarakat seperti sawi, kangkung, dan lobak hari; (2) Tahap pelatihan secara langsung tentang cara pengolahan pekarangan rumah menjadi media menanam sayuran, yang dilaksanakan di salah satu tempat yang telah disediakan oleh masyarakat, proses pelatihan dilakukan secara bertahap, mulai dari pembukaan lahan, pemberian pupuk organik pada lahan yang telah diolah, hingga pada tahapan melakukan pembibitan; (3) Tahap mendampingi masyarakat dalam mengelola dan merawat sayuran yang telah ditanam; (4) Tahap pendampingan kepada masyarakat dalam memasarkan produk yang dihasilkan dari lahan pekarangan rumah, dengan melakukan kerjasama dengan pedagang sayur. Dalam hal ini pendampingan kepada 10 (sepuluh) orang anggota masyarakat.

Tabel 1. Struktur Kelompok Masyarakat

\begin{tabular}{|c|c|c|}
\hline No & Jabatan & Nama \\
\hline 1. & Ketua & $\begin{array}{l}\text { Muhammad Farhan } \\
\text { Nur }\end{array}$ \\
\hline 2. & Bendahara & Iwan Tompo \\
\hline 3. & Koordinator & Subair Lassa \\
\hline 4. & Anggota & $\begin{array}{l}\text { Dahlan Joa, } \\
\text { Notopoa, Berliana, } \\
\text { Ramla, Muhiding } \\
\text { Tutu, Iksan Sore, } \\
\text { Eden Nai }\end{array}$ \\
\hline
\end{tabular}

Sumber : Penulis, 2020

\section{Hasil dan Pembahasan}

Kegiatan pemanfaatan lahan pekarangan rumah yang dilaksanakan di desa 
Kalenna Bontomangape berlangsung selama 60 hari, lahan yang tidak terpakai diolah menjadi media untuk menanam berbagai macam jenis sayuran seperti lobak dan sayuran lainnya. Kegiatan ini dilakukan dengan beberapa tahapan yaitu edukasi, pelatihan, pengelolaan, hingga pendampingan pemasaran.

Memberikan edukasi melalui kegiatan sosialisasi kepada masyarakat di salah satu tempat yang telah disediakan, kegiatan sosialisasi dilakukan selama dua hari. Materi yang diberikan kepada masyarakat, mengenai manfaat dalam mengolah tanah di pekarangan rumah menjadi lahan yang dapat menghasilkan keuntungan ekonomis dan sebagai sarana pemenuhan pangan keluarga serta pengenalan tanaman lobak.

Sosialisasi pada hari pertama memberikan edukasi mengenai cara mengelola dan memanfaatkan lahan pekarangan rumah yang selama ini tidak pernah dimanfaatkan, kegiatan ini berlangsung selama 2 (dua) jam dimana masyarakat aktif dalam memberikan pertanyaan mengenai cara me-manfaatkan lahan pekarangan rumah, pada hari kedua materi yang diberikan lebih mengacu pada pengenalan tanaman sayur (lobak) yang selama ini tidak mengenal jenis tanaman ini dikarekan kurangnya informasi yang mereka dapatkan. Informasi yang disampaikan mengenai tanaman lobak ini yaitu cara menanam,merawat,dan masa panen yang hanya memakan waktu 45 hari setelah lobak ditanam di lahan yang telah disiapkan.

Memberikan pelatihan kepada masyarakat yang sebelumnya telah diberikan edukasi tentang pemanfaatan dan pengolahan lahan pekarangan rumah. Pelatihan meliputi; (1) Pembukaan lahan pekarangan rumah dengan membersihkan lahan yang ditumbuhi rumput liar menggunakan cangkul agar lahan menjadi bersih sekaligus untuk menggemburkan tanah. (2) Pemberian pupuk kandang berupa kotoran bebek yang telah mengering, pupuk kandang ditaburkan diatas lahan yang telah digemburkan dengan merata, kemudian tanah diaduk hingga pupuk kandang tercampur sepe-nuhnya dengan tanah. (3) Setelah lahan siap kemudian dilakukan penanaman bibit lobak dengan cara melobangi tanah menggunakan jari dengan kedalaman sekitar 1-1.5 cm dengan mengatur jarak antara satu lobang dengan lobang lainnya dengan jarak tanam 15-20 cm, setelah semua bibit dimasukkan kedalam lobang yang telah dibuat sebelumnya, kemudian lobang ditaburi tanah secukupnya hingga tertutup. Terakhir lahan yang telah yang berisi bibit lobak disiram secukupnya hingga tanah menjadi basah sepenuhnya.

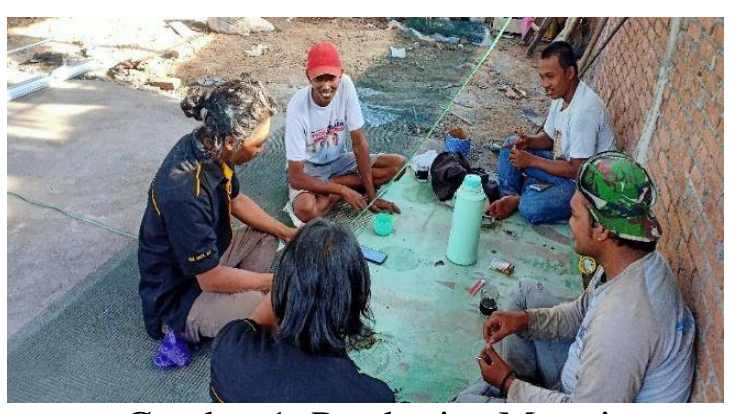

Gambar 1. Pemberian Materi

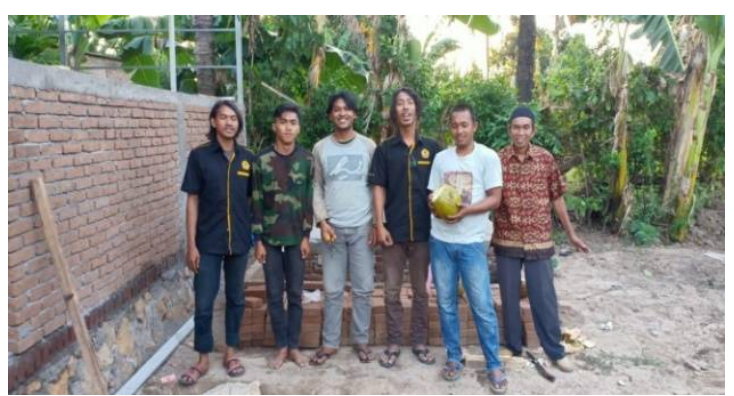

Gambar 2. Foto Kelompok Masyarakat

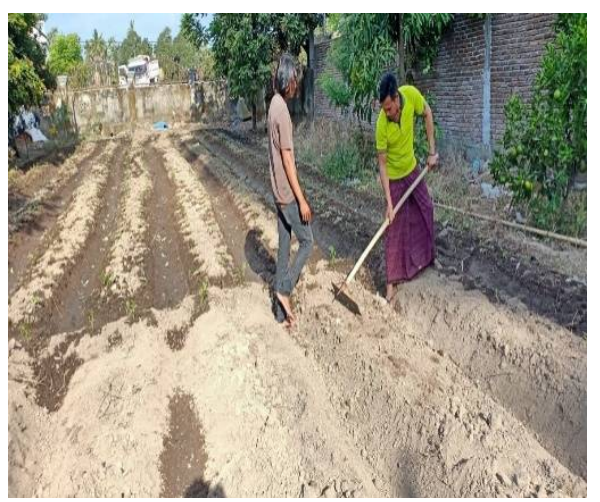

Gambar 3. Pengolahan Tanah 


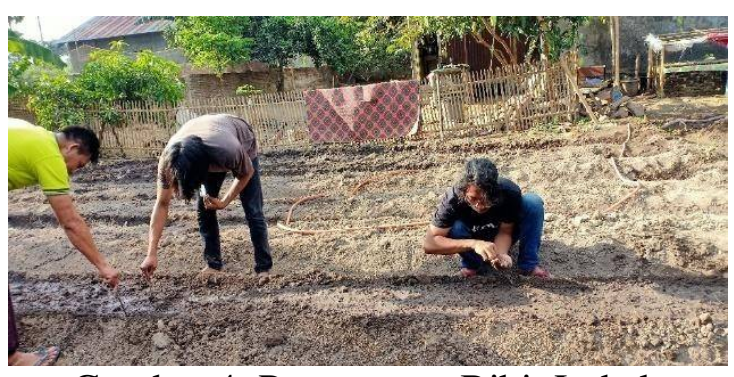

Gambar 4. Penanaman Bibit Lobak

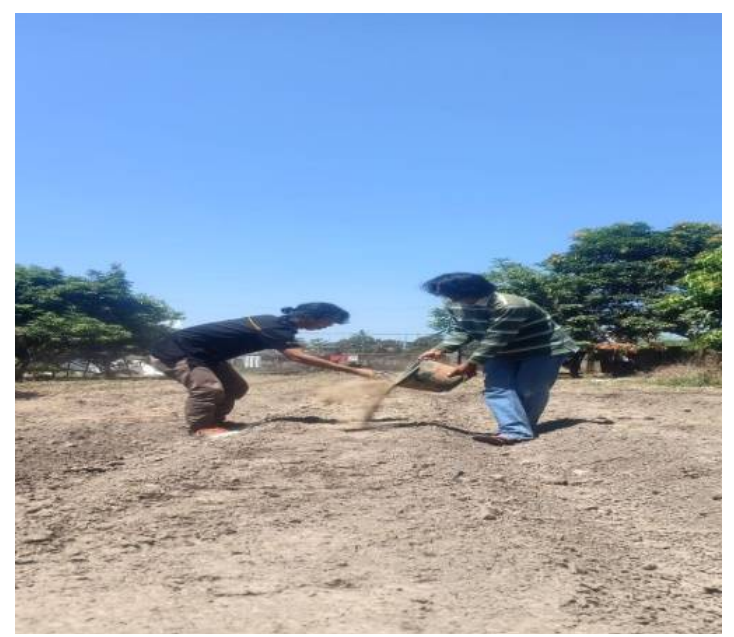

Gambar 5. Pemberian Pupuk

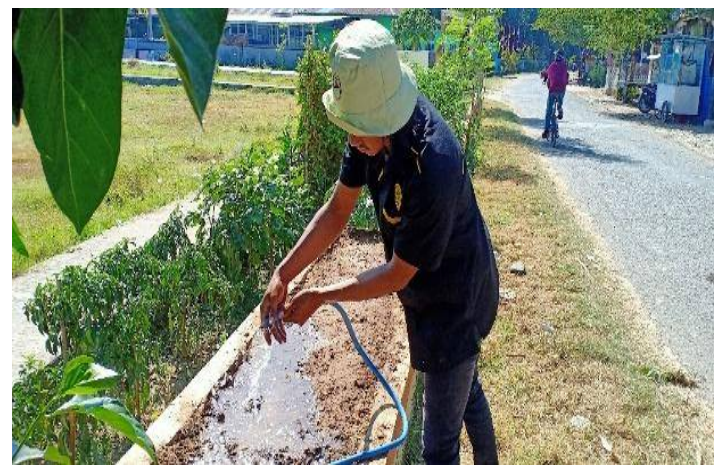

Gambar 6. Penyiraman

Melakukan pendampingan kepada masyarakat dalam merawat dan mengelola lahan yang telah ditanami lobak, proses pendampingan dilakukan secara bertahap, masyarakat diarahkan untuk melakukan penyiraman $1 \mathrm{x}$ dalam rentang waktu 2 hari, ini dilakukan agar tanah tidak kering dan juga tidak terlalu basah, karena tanaman lobak butuh suplai air yang cukup, selain itu dilakukan pemantauan pertumbuhan lobak sampai dirasa cukup untuk melakukan pemberian pupuk pertama pada sayuran (lobak), rentang waktu lobak siap dipupuk saat berumur 8-12 hari, ini dilakukan untuk mempercepat proses pertumbuhan sayur, kemudian pemantauan terus dilanjutkan sampai pemberian pupuk kedua, pada proses pemupukkan kedua dilakukan saat sayuran lobak berumur 21 (dua puluh satu) hari,dimana pada saat ini lobak siap untuk berbuah. Proses pendampingan kepada masyarakat dilakukan secara bertahap hingga sampai masa panen tiba.

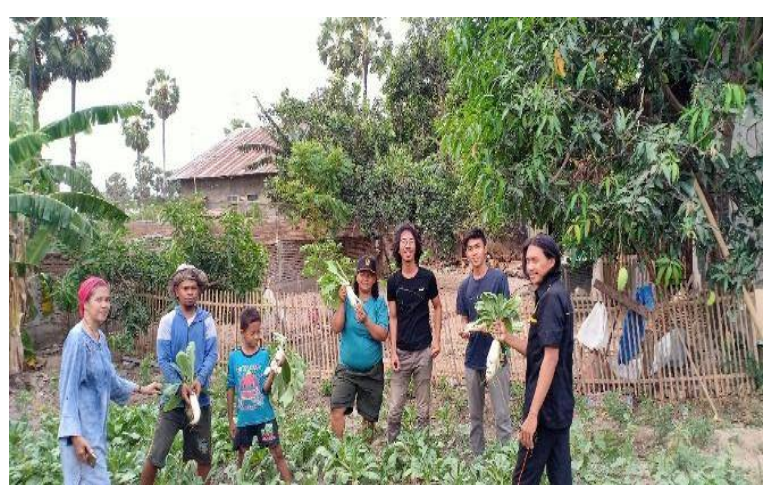

Gambar 7. Panen Lobak

Setelah 45 (empat puluh) hari penanaman, sayuran lobak siap untuk dipanen. Dari minimnya pengetahuan masyarakat dalam memasarkan produk tanaman lobak maka dilakukan pendampingan yang bertujuan agar masyarakat dapat memasarkan sayuran lobak, Selain untuk dijual sayuran lobak juga menjadi pemenuhan pangan keluarga, Dari lahan 5x5 meter masyarakat dapat menghasilkan 125 biji sayuran lobak atau sekitar 30-35 kg, masyarakat rata-rata menjual 100 (seratus) biji lobak atau sekitar 20-25 kg sekali panen. Untuk 1 (satu) biji lobak (250gram) dijual dengan harga Rp. 3.000,- atau Rp. $12.000 / \mathrm{kg}$, maka masyarakat mendapatkan penghasilan tambahan rata-rata sebanyak Rp.300.000,- dalam sekali panen untuk tanaman sayur lobak.

Kegiatan yang dilaksanakan bersama kelompok masyarakat dalam rangka pemanfaatan lahan pekarangan rumah dengan tujuan agar terpenuhinya kebutuhan pangan keluarga dan juga sebagai sumber penghasilan tambahan dari hasil penjualan berupa sayuran mayur seperti lobak, dan 
sayuran lainnya. Yang kaya akan sumber vitamin. Vitamin merupakan kelompok senyawa organik yang tidak termasuk dalam golongan protein, karbohidrat maupun lemak. (Moch, agus Krisno Budiyono. 2004:51). Sebelum masyarakat memanfaatkan lahan pekarangan rumah, banyak lahan tidur yang tidak digarap oleh masyarakat, salah satunya pekarangan rumah yang kebanyakan hanya menjadi tempat tumbuhnya tanaman liar dan sarang nyamuk. Dengan adanya kegiatan pemanfaatan lahan pekarangan rumah untuk menanam berbagai jenis sayuran, selain mendapatkan hasil pertanian untuk pemenuhan kebutuhan rumah tangga, masyarakat dapat menata pekarangan rumah mereka menjadi indah serta memiliki nilai estetika serta lingkungan yang bersih.

Kegiatan pemanfaatan lahan ini dapat dilakukan oleh semua golongan masyarakat dikarenakan dalam proses pengolahannya yang mudah dan dengan modal yang minim.Sumber utama pendapatan biasanya didefinisikan oleh Makeham dan Malcom (2003), adalah hasil penjualan produksi tanaman atau hasil tanaman. Keuntungan usaha tani tidak ditentukan oleh tingginya pendapatan dari satu cabang produksi. Keuntungan akhir dari satu tahun kerja yang bersih ditentukan oleh keseluruhan cabang usahatani yang diusahakan. Apabila terdapat lebih dari satu cabang usaha, seorang petani akan dihadapkan pada kombinasi mana yang baik sehingga didapatkan keuntungan yang setinggi-tingginya dalam setahun.

Dari rata-rata luas lahan pekarangan rumah masyarakat yang tidak dimanfaatkan adalah 5x5 meter, ini dapat dijadikan sebagai media menanam sayuran seperti lobak, sawi, kangkung, dan tanaman lainnya, dengan adanya kegiatan pemanfaatan lahan pekarangan rumah, masyarakat dapat melakukan penghematan Rp.84.000/minggu, dari rata-rata setiap keluarga mengeluarkan biaya Rp.12.000/hari untuk membeli sayuran. Dengan demikian pemanfaatan lahan menjadi sesuatu yang dapat memberikan kontribusi kepada ma- syarakat, serta mengurangi biaya pengeluaran untuk membeli kebutuhan dapur.

Sehingga kegiatan ini dapat memberdayakan masyarakat dari aspek gizi dan kebutuhan ekonomi, serta dapat memaksimalkan sumber daya yang dimiliki khususnya lahan pekarangan rumah yang dapat lebih produktif. Oleh karena itu kegiatan ini dapat dilaksanakan secara terus menerus dan dapat dijadikan sebagai program pemerintah desa Kalenna Bontomangape.

\section{Simpulan}

\section{Penutup}

Program pemanfaatan lahan pekarangan rumah sangat diminati oleh masyarakat, terbukti dari antusiasnya masyarakat dalam mengikuti program ini, selain terpenuhinya kebutuhan pangan keluarga, masyarakat juga mendapatkan keuntungan dari hasil penjualan sayur. Setiap keluarga yang mengikuti program pemanfaatan lahan pekarangan rumah dapat menghasilkan pendapatan rata-rata sebanyak Rp.300.000 sekali panen. Sehingga kegiatan ini memberikan manfaat secara langsung dari aspek terpenuhi kebutuhan gizi dan meningkatkan kesejahteraan masyarakat dari aspek peningkatan pendapatan.

Saran

Pemerintah desa Kalenna Bontongape diharapkan dapat melanjutkan dan mengembangkan program dalam wujud program Desa. Karena kegiatan ini terbukti diminati oleh masyarakat karena dapat me-menuhi kebutuhan pangan keluarga dan menjadi sumber pendapatan baru. Begitu juga dengan masyarakat agar dapat melan-jutkan program ini, serta mengembangkan jenis tanaman sayur lainnya untuk mendapatkan hasil yang lebih maksimal, dan kedepannya jumlah masyarakat yang meman-faatkan lahan pekarangan rumah semakin banyak.

\section{Ucapan terima kasih}

Dengan suksesnya kegiatan pemanfaatan lahan pekarangan rumah, kami me- 
ngucapkan terima kasih kepada pemerintah desa Kalenna Bontomangape dan bapak camat Galesong, serta masyarakat yang terlibat langsung dalam kegiatan pemanfaatan pekarangan rumah yang berlangsung selama 60 hari di desa Kalenna Bontongape.

\section{Daftar Pustaka}

Dwiratna, N. P. S., Widyasanti, A., \& Dan Rahmah, D. M. 2016. Pemanfaatan lahan pekarangan dengan menerapkan konsep kawasan rumah pangan lestari. Dharmakarya: Jurnal Aplikasi Ipteks Untuk Masyarakat, 5(1).

https://takalarkab.bps.go.id/publication/do wnload.html diaksese pada tanggal 7 Juni 2020 pada pukul 18;50.

Makeham dan Malkcom (2003),: Ekologi Desa : Lingkungan Hidup dan Kualitas Hidup. Prisma, No, 8, September 2003.

Mestre-Sanchís, F., M.L. Feijóo-Bello. 2009. Analysis Climate change and its marginalizing effect on agriculture. Ecological Economics 68:896-904.

Moch. Agus Krisno Budiyono, 2004. Dasar-dasar ilmu Gizi. Malang: Universitas Muhammadiyah Malang.

Riah. 2005. Pemanfaatan Lahan Pekarangan. Penebar Swadaya. Jakarta.

Rauf, A., Rahmawaty, \& Budiati, D. 2013. Sistem pertanian terpadu di lahan pekarangan mendukung ketahanan pangan berkelanjutan dan berwawasan lingkungan. Jurnal Online Pertanian Tropik Pasca Sarjana FP USU, 1(1).

Supriati, Y.Yuyu Yulia dan Ida Nurlaela. 2008. Tanaman Sayur. Penerbit Penebar Swadaya Jakarta. Hal. 15. 